\title{
Characteristics of highly active carboxylesterases in insecticide-resistant Culex pipiens quinquefasciatus
}

\author{
Yoshiaki Kono* and Takashi Tomita* \\ Department of Medical Entomology, National Institute of Health, \\ Shinjuku-ku, Tokyo 162, Japan
}

(Received: April 22, 1992)

Key words: carboxylesterase, insecticide resistance, Culex.

\begin{abstract}
Three carboxylesterases (CE's) were separated by PAGE from an organophosphate resistant Culex pipiens quinquefasciatus (Okinawa strain). The first CE was found specifically in the alimentary canal and the second CE distributed throughout the larval body. These CE's were monomeric protein (MW: 60,000) and were categorized as B-type CE. The third $\mathrm{CE}$ was a homodimeric protein (MW: ca. 120,000) categorized as A-type CE and detected in all parts except the haemolymph. All CE's showed the characteristic inhibition pattern with organophosphates and carbamates, but their low dissociation constants indicated that the CE's had no hydrolyzing activity against these chemicals. It was supposed from the data presented that the GE's sequestered insecticides and prevented their access to the target, AChE in the central nervous system.
\end{abstract}

\section{INTRODUCTION}

It has been reported that the high activity of carboxylesterase $(\mathrm{CE})$ is closely related with organophosphorus insecticide resistance in Culex mosquitoes (Matsumura and Brown, 1961, 1963; Yasutomi, 1970, 1983; Georghiou and Pasteur, 1978). Recently, a large amount of the enzyme protein produced by amplified gene has been elucidated as the cause of the high CE activity (Mouches et al., 1986, 1987).

Two bands of highly active CE's were found on agar gel electrophoresis in the Okinawa strain of Culex pipiens quinquefasciatus which showed strong resistance to malathion and a low level of resistance to other organophosphorus insecticides (Yasu-

\footnotetext{
* 河野義明, 富田隆史: 国立予防衛生研究所昆虫医科 学部（干162 東京都新宿区戸山 1-23-1)
}

tomi, 1983). These CE's were proved to hydrolyze malathion (Miyata et al., 1984a, b). Insect CE's, on the other hand, were shown to have another role in insecticide detoxication, first named "sequestering" by Devonshire and Moores (1982) in their study on the peach-potato aphid, Myzus persicae, through which insecticides or their active metabolites conjugate with the $\mathrm{CE}$ and consequently are prevented from their access to the target. This kind of mechanism seems to be important in the resistant Culex mosquitoes which have a large amount of CE's.

In the present paper, characteristics of highly active CE's in the Okinawa strain of $C$. pipiens quinquefasciatus were compared with those having already been clarified in the Culex mosquitoes (Fournier et al., 1987; Merryweather et al., 1990; Pasteur et al., 1981; Raymond et al., 1987; Wirth et al., 1990). Further, inhibition of the CE activity by various insecticides and synergists, and 
the recovery of the activity of inhibited CE were measured to elucidate the sequestering specificity of CE's.

\section{Materials and Methods}

Insects. Okinawa strain of $C$. pipiens quinquefasciatus originated from an open sewer population in Koza, Okinawa, was used with a reference strain, Ogasawara, which was collected in Chichijima, Ogasawara Islands. These strains were maintained in the laboratory without exposure to insecticides.

Chemicals. A saligenin cyclic synergist, K-2, was received from Prof. M. Eto, Kyushu University. Fenitroxon (99\% in purity) was received from Sumitomo Chemical Co., Ltd., metolcarb (100\%) and MTMC-Z (99\%) from Mitsubishi Chemical Industries Ltd., pyraclofos $(99 \%)$ from Takeda Chemical Industries Ltd., and propoxur (98\%) from Nihon Tokushu Noyaku Seizo Ltd. Other insecticides and synergists, triphenyl phosphate (TPP), di-isopropyl fluorophosphate (DFP) and S-benzoyl di-isopropyl phosphorothioate (IBP), were analytical standards from Wako Chemical Industries Ltd. except diazoxon which was produced by oxidating diazinon with equimolar meta-chloroperbenzoic acid. Protein molecular weight markers for Ferguson's plot analysis were purchased from Sigma Chemical Co. All the chemicals used in the experiments were analytical grade.

Anti-CE antiserum. A highly active CE in organophosphorus insecticide-resistant strain "Shinjuku" of $C$. pipiens molestus whose structural gene sequences ( $360 \mathrm{bp}$ ) had been analyzed to be the same as those of B1 CE in C. pipiens quinquefasciatus (Mouches et al., 1990; Tomita and Shimada, 1991) was separated by PAGE. The CE protein was extracted from the cut gel disc containing the activity and used to immunize mice as antigen. The antiserum obtained was proved to be specific to the highly active CE in the Shinjuku strain.

Preparation of mosquito extracts. For electrophoresis, 5 larvae of the last instar or 10 adults of 3-4 days old were homogenized in $0.5 \mathrm{ml}$ of phosphate buffer solution $(0.0375$ м $\mathrm{KH}_{2} \mathrm{PO}_{4}+0.0214 \mathrm{~m} \quad \mathrm{Na}_{2} \mathrm{HPO}_{4}, \mathrm{pH} \quad 6.8$, PBS) and centrifuged at $2,000 \times g$ for $15 \mathrm{~min}$ at $4^{\circ} \mathrm{C}$. Five alimentary canals which were dissected out and the remainder (called carcass) containing integument, fat body, muscle and nerve were rinsed with PBS, homogenized in $0.25 \mathrm{ml}$ PBS and centrifuged. Twenty microliters of the supernatant was applied on a polyacrylamide gel electrophoresis (PAGE) column and $5 \mu$ l of the supernatant on a lane of slab PAGE.

For the haemolymph, a small piece of filter paper absorbing the haemolymph equivalent to the total amount of the haemolymph of two larvae was applied on the disc PAGE.

Detection of CE activity. CE's of the mosquitoes were electrophoresed by disc PAGE $(5 \times 50 \mathrm{~mm}, 7.5 \%, \mathrm{pH} 7.5)$, using $8 \mathrm{~mm}$ Tris-barbital buffer $(\mathrm{pH} 7.0)$ as an electrode buffer. After the separation, the gel columns were incubated in the phosphate buffer solution containing $0.01 \% \quad \alpha$-naphtylacetate $(\alpha$-NA) and/or $0.01 \% \beta$-naphtylacetate $(\beta$-NA) as a substrate and $0.1 \%$ fast violet $\mathrm{B}$ salt at $30^{\circ} \mathrm{C}$ for $20 \mathrm{~min}$ for the detection of $\mathrm{CE}$ activity. CE activity in the gel was recorded by scanning with a computing densitometer (ACD-25BS, Atto Co. Ltd.) at $525 \mathrm{~nm}$ of wavelength.

For the evaluation of the inhibitory activities of insecticides and synergists against the CE's, the gel disc electrophoresed was incubated in the test chemical solutions before detecting activity. Inhibition percentage was calculated by comparing the densities of corresponding bands with the enzyme activity (peak area of the scanning chart) between test and control gel discs.

To measure the recovery of $\mathrm{CE}$ activity, the esterases were inhibited by adding a high concentration of inhibitors (fenitroxon $5 \times$ $10^{-5}$, dichlorvos $5 \times 10^{-6}$, DFP $5 \times 10^{-6}$, carbaryl $\left.2.5 \times 10^{-4} \mathrm{M}\right)$ before the electrophoresis. The activities were measured 0,1 and $2 \mathrm{hr}$ after electrophoresis and the recovery of the activity was calculated.

Fast violet $B$ salt was replaced by fast blue RR salt when the substrate specificity of the CE was investigated. The gel disc colored was scanned at several wave lengths between 400 and $600 \mathrm{~nm}$.

Ferguson's plot. The supernatant was electrophoresed in disc PAGE of 7, 8, 9 and $10 \%$ acrylamide $(10 \mathrm{~cm}$ in height, $\mathrm{pH} 6.7)$ 
using Tris-glycine electrode buffer ( $\mathrm{pH}$ 8.3). Molecular weight markers were bovine milk $\alpha$-lactalbumin (MW: 14,200), bovine erythrocyte carbonic anhydrase $(29,000)$, chicken egg albumin $(45,000)$ and bovine serum albumin (monomer: 66,000, dimer: 132,000 ).

CE's and marker proteins were detected by enzyme reaction and coomassie brilliant blue $\mathrm{R}$ staining, respectively, and then electrophoretic mobilities $(R f)$ of each $\mathrm{CE}$ and marker were measured on gels of 4 different polyacrylamide concentrations.

According to the method of Bryan (1977), $100 \log (R f \times 100)$ was plotted against the percent gel concentration for each $\mathrm{CE}$ and marker. The slope of the plot (retardation coefficient) was determined, and the logarithm of the negative slope was plotted against the logarithm of the molecular weight of each marker. On the linear relationship given, molecular weights of the CE's could be estimated from their logarithm of the negative slope.

SDS PAGE and immunological detection. Adult CE's were separated by native disc PAGE and the CE bands excised were applied to SDS-PAGE. Separated monomer proteins were blotted on an Immobilon ${ }^{\text {TM }}$ sheet. Immunological reaction with the anti$\mathrm{CE}$ antibodies was detected using the secondary antibody (anti-mouse IgG) conjugated horse radish peroxidase.

\section{RESUlts}

\section{CE in "Okinawa" strain}

Three major bands with CE activity were detected from the whole body homogenate of 4th instar larvae of the Okinawa strain. of $C$. pipiens quinquefasciatus by PAGE. They were named EI (Rf: 0.52), EII (0.31) and EIII (0.23) from the front side (Fig. 1, top). Two bands, EI' (0.48) and EII' (0.28) (named in the same manner as the Okinawa strain) were detected in the larvae of the reference strain "Ogasawara" (Fig. 1, bottom). Mobility of EII' was between EII and EIII. When the supernatant of the homogenized alimentary canal and carcass, and haemolymph were electrophoresed, EI existed specifically in the alimentary canal, EII distributed to every part, and the haemolymph mainly contained EII and a small amount of EIII (Fig. 1, middle three columns).

Electrophoresis of the adult extract showed that EI and $\mathrm{EI}^{\prime}$ were diminished and the relative activity of EII to EIII in the Okinawa strain was higher than that in the larval stage (Fig. 2). EII and EIII activities

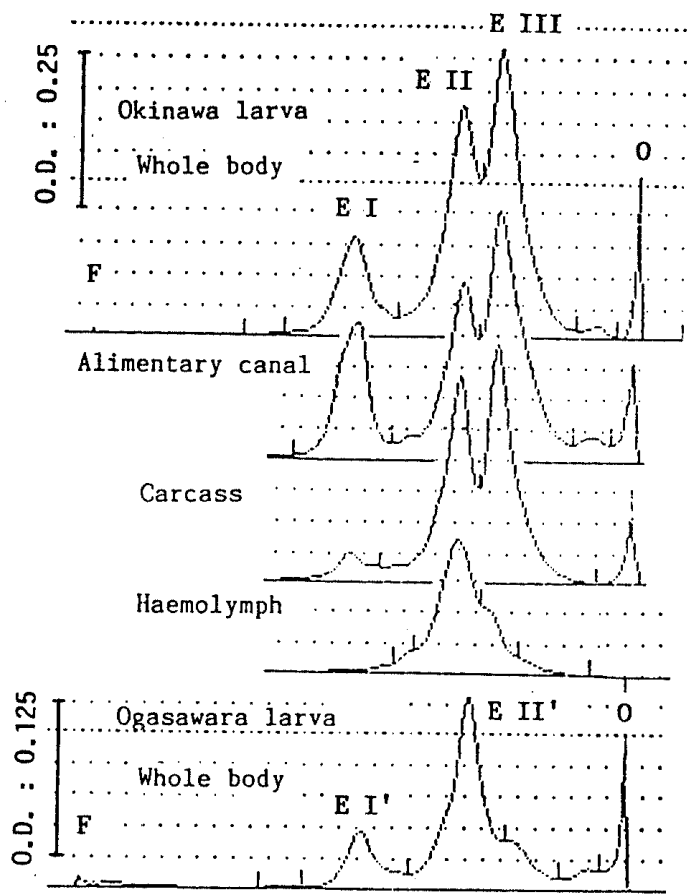

Fig. 1 Densitometric scanning of $\mathrm{CE}$ in $C$. pipiens quinquefasciatus (Okinawa and Ogasawara strains) larvae on $7.5 \%$ polyacrylamide gel electrophoresis.

F, front; $O$, origin. Ordinate: Optical density (O.D.).

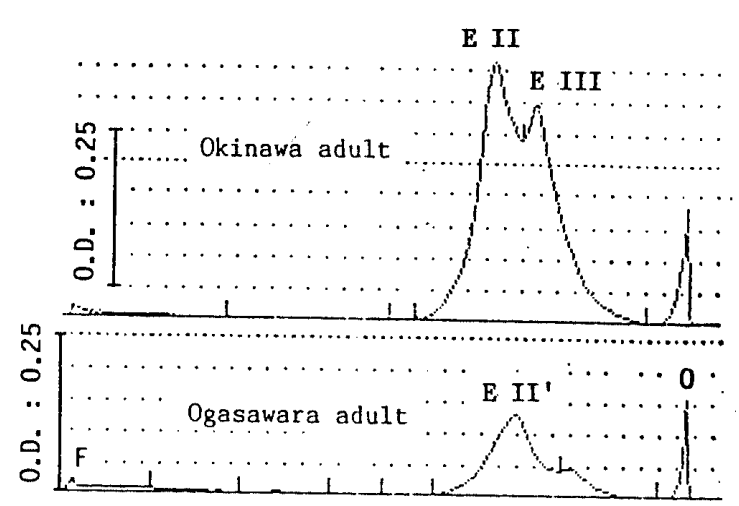

Fig. 2 Comparison of adult CE activities between two strains, Okinawa and Ogasawara, by densitometric scanning.

F, front; $O$, origin. Ordinate: Optical density (O.D.). 
were about three times higher than EII' activity.

\section{Substrate specificity}

After the separation of CE's by PAGE, the activity was measured using $\alpha$-NA, $\beta$-NA and $1: 1$ mixture of both as the substrate and fast blue $R R$ salt as a detecting pigment. According to this method, hydrolyzing activity to $\alpha$-NA and $\beta$-NA could be distinguished by the colors, brownish-red and purplish-pink. The stained gel column was scanned with different wavelengths. Optical densities of each CE band were plotted against wave lengths in Fig. 3. Curve a shows the sum of activities of $\alpha$-NA and $\beta$ NA. Curve $b$ is an amplified $\beta$-NA curve, in which the $\mathrm{OD}_{400}$ is adjusted to that of $\alpha$-NA $+\beta$-NA curve. When the mixture of $\alpha$ - and $\beta$-NA was used as substrate, there was considerable difference in hydrolyzing activity between EII and EIII. The activity of EIII showed a curve similar to the sum of activities of two components $\alpha$ - and $\beta$-NA as substrate (a). On the other hand, EII showed a very similar curve to the ideal curve b. These results indicate that EII mainly hydrolyzes $\beta$-NA and its activity is enhanced by the co-existence of $\alpha$-NA, while EIII hydrolyzes both $\alpha$-NA and $\beta$-NA at the same rate regardless of the substrate conditions, single or mixed substrates. EII' curve of the Ogasawara strain showed a similar shape to curve a.

\section{Molecular weight of the CE's}

Native molecular weight of the CE's was measured according to Ferguson's plot. Retardation coefficient $\left(K_{\mathrm{r}}=100 \log (R f \times 100) /\right.$ per cent gel conc.) of the standard proteins was calculated from relative mobilities $(R f)$ on 7, 8, 9 and $10 \%$ gels and $-K_{\mathrm{r}}$ value of each protein was plotted against the molecular weight in logarithm scale as shown in Fig. 4. A linear plot was obtained. Using the line, molecular weights of EI $\left(-K_{\mathrm{r}}\right.$ : 6.83), EII (6.83) and EIII (10.33) were determined to be $60,000,60,000$ and 120,000 , respectively. SDS PAGE of EII and EIII indicated that the molecular weights of unit protein of these CEs were 60,000 and 65,000, respectively (data not shown) and suggested that EII is a monomer protein and EIII is a homodimer protein.

\section{Discrimination of the $C E$ by antiserum}

EII and EIII separated by native PAGE were applied to SDS-PAGE and blotted on
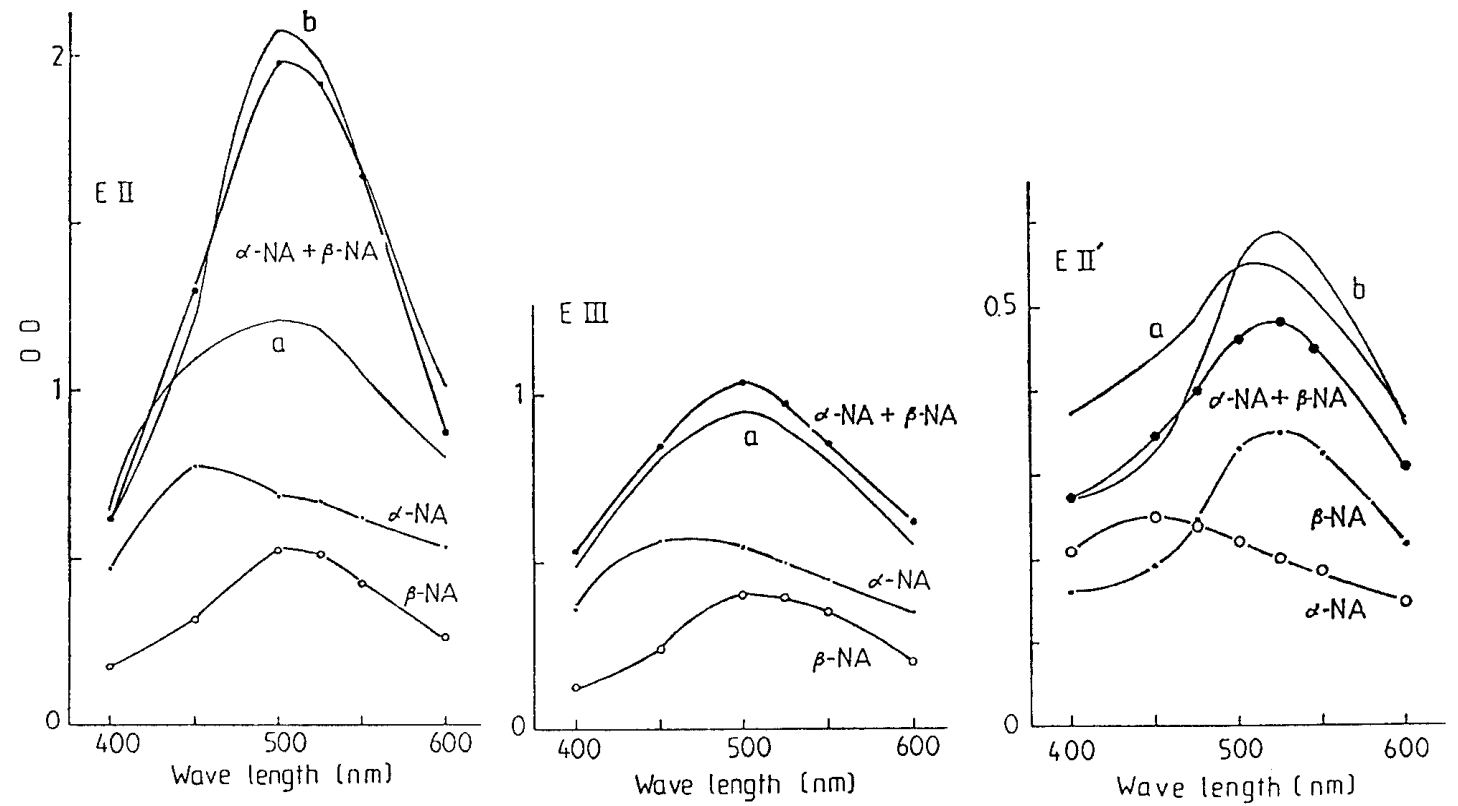

Fig. 3 Substrate specificity of CE's in Okinawa (EII, EIII) and Ogasawara (EII') strains. $\alpha$-NA, $\beta$-NA and $\alpha$-NA $+\beta$-NA curves indicate hydrolyzing activity using corresponding substrates. Curve a, sum of activities of $\alpha$-NA and $\beta$-NA; curve b, amplified $\beta$-NA curve adjusting $\mathrm{OD}_{400}$ value to that of $\alpha-\mathrm{NA}+\beta-\mathrm{NA}$ curve. 


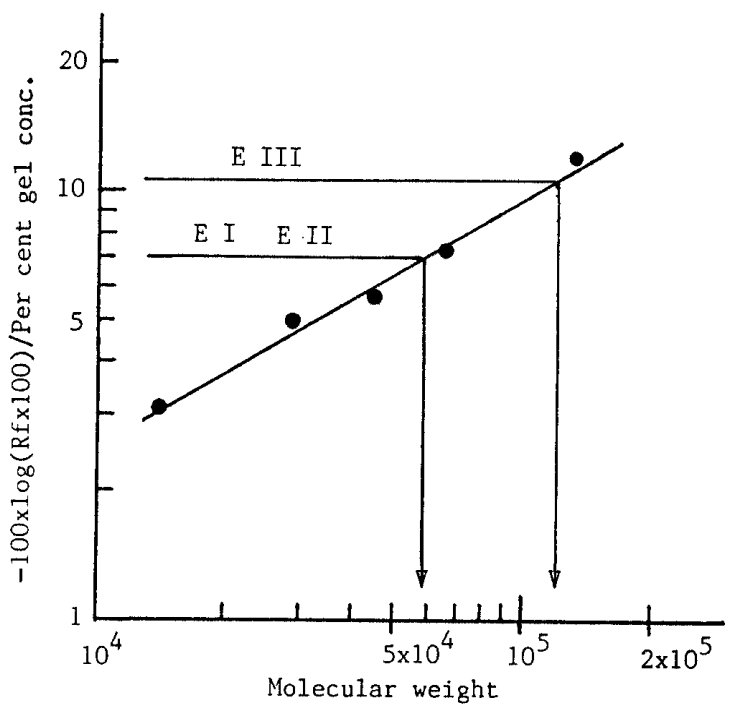

Fig. 4 Estimation of the molecular weight of CE's of Okinawa strain on the Ferguson's plot.

Molecular weight standards used were $\alpha$ lactalbumin, 14,200; carbonic anhydrase, 29,000; chicken egg albumin, 45,000; and bovine serum albumin, monomer: 66,000, dimer: 132,000 .

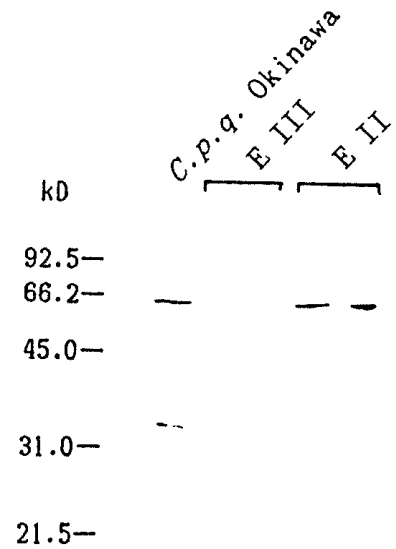

Fig. 5 Immunoblotting of EII and EIII CE's of Okinawa strain with antiserum to $\mathrm{CE}$ (B-type) of Shinjuku strain.

One adult equivalent of extract (C.p.q. Okinawa), and one (left lane) and three (right lane) adults equivalent of EIII and EII fractions (EIII and EII, respectively) were electrophoresed with SDS.

Immobilon ${ }^{\mathrm{TM}}$ membrane. On the membrane, these CE's were tested for immunological cross-reaction to the antiserum against B-type $\mathrm{CE}$ (CE-B) in the Shinjuku strain of $C$. pipiens molestus. Apparent immunological
Table 1 Inhibition of CE's of Okinawa strain with insecticides and synergists.

\begin{tabular}{|c|c|c|c|c|}
\hline \multirow{2}{*}{ Chemical } & \multirow{2}{*}{$\begin{array}{l}\text { Molar } \\
\text { conc. }\end{array}$} & \multicolumn{3}{|c|}{$\%$ inhibition } \\
\hline & & $\mathrm{EI}$ & EII & EIII \\
\hline \multirow[t]{2}{*}{ Fenitroxon } & $10^{-6}$ & 100 & 23.1 & 31.6 \\
\hline & $10^{-5}$ & 100 & 90.1 & 57.2 \\
\hline \multirow[t]{2}{*}{ Diazoxon } & $10^{-7}$ & 100 & 92.7 & 70.5 \\
\hline & $10^{-6}$ & 100 & 97.6 & 92.6 \\
\hline \multirow[t]{2}{*}{ Dichlorvos } & $10^{-7}$ & 80.0 & 65.9 & 89.7 \\
\hline & $10^{-8}$ & 90.0 & 92.7 & 94.1 \\
\hline \multirow[t]{2}{*}{ Pyraclofos } & $10^{-5}$ & 100 & 40.9 & 47.6 \\
\hline & $10^{-4}$ & 100 & 78.2 & 64.2 \\
\hline \multirow[t]{2}{*}{ Carbaryl } & $10^{-5}$ & 68.9 & 0 & 58.8 \\
\hline & $10^{-4}$ & 95.6 & 16.9 & 88.1 \\
\hline \multirow[t]{2}{*}{ Metolcarb } & $10^{-5}$ & 5.6 & 0 & 30.7 \\
\hline & $10^{-4}$ & 58.3 & 0 & 67.1 \\
\hline \multirow[t]{2}{*}{ MTMG-Z } & $10^{-5}$ & 48.9 & 51.9 & 66.7 \\
\hline & $10^{-4}$ & 91.1 & 81.2 & 88.0 \\
\hline \multirow[t]{2}{*}{ Propoxur } & $10^{-5}$ & 16.7 & 0 & 0.6 \\
\hline & $10^{-4}$ & 66.7 & 0 & 0 \\
\hline \multirow[t]{2}{*}{ TPP } & $10^{-6}$ & 3.7 & 52.0 & 8.4 \\
\hline & $10^{-5}$ & 43.2 & 90.6 & 12.5 \\
\hline \multirow[t]{2}{*}{$\mathrm{K}-2$} & $10^{-8}$ & 100 & 97.7 & 71.2 \\
\hline & $10^{-7}$ & 100 & 100 & 86.2 \\
\hline \multirow[t]{2}{*}{ DFP } & $10^{-8}$ & 67.4 & 17.5 & 56.7 \\
\hline & $10^{-7}$ & 82.9 & 94.9 & 86.5 \\
\hline \multirow[t]{2}{*}{ IBP } & $10^{-6}$ & 84.5 & 10.1 & 17.6 \\
\hline & $10^{-5}$ & 92.2 & 7.8 & 50.4 \\
\hline \multirow[t]{2}{*}{ Pyrimicarb } & $10^{-5}$ & 68.5 & 24.5 & 39.3 \\
\hline & $10^{-4}$ & 100 & 62.6 & 80.3 \\
\hline
\end{tabular}

cross-reaction was observed in EII but not in EIII as shown in Fig. 5.

\section{Inhibition of CE's with insecticides and synergists}

Inhibitory activity of various insecticides and synergists was evaluated by incubation of the gel disc in their solutions followed by the enzyme reaction. The results are summarized in Table 1. Diazoxon, dichlorvos, K-2 and DFP showed potent inhibitory ac- 
Table 2 Inhibition of CE's of Ogasawara strain with insecticides and synergists.

\begin{tabular}{lccc}
\hline \multirow{2}{*}{ Chemical } & $\begin{array}{c}\text { Molar } \\
\text { conc. }\end{array}$ & \multicolumn{2}{c}{ \% inhibition } \\
\hline Fenitroxon & $10^{-5}$ & 100 & 91.2 \\
Carbaryl & $10^{-5}$ & 75.3 & 57.1 \\
& $10^{-4}$ & 91.1 & 83.2 \\
TPP & $10^{-5}$ & 2.2 & 35.3 \\
DFP & $10^{-5}$ & 81.3 & 88.2 \\
IBP & $10^{-5}$ & 49.5 & 88.2 \\
\hline
\end{tabular}

Table 3 Recovery of inhibited GE activity of Okinawa strain.

\begin{tabular}{lcc}
\hline Inhibitor & $\begin{array}{c}k_{3} \text { value }(/ \mathrm{hr}) \text { and time necessary } \\
\text { for } 50 \% \text { recovery in parenthesis }\end{array}$ \\
\cline { 2 - 3 } & EII & EIII \\
\hline Fenitroxon & $0.041(17 \mathrm{hr})$ & 0 \\
Dichlorvos & $0.095(7 \mathrm{hr})$ & $0.086(8 \mathrm{hr})$ \\
Carbaryl & $0.223(3 \mathrm{hr})$ & $0^{*}$ \\
DFP & $0.029(23 \mathrm{hr})$ & $0.015(43 \mathrm{hr})$ \\
\hline
\end{tabular}

* Eighty per cent of the activity was recovered during the electrophoresis, although the recovery was not detected after the electrophoresis.

tivity to every band of $\mathrm{CE}$ in the Okinawa strain. Fenitroxon had strong inhibitory activity to EI and moderately strong to EII but not so strong to EIII. Pyraclofos, a S-n-propyl O-ethyl organophosphorothioate, showed strong activity only to EI.

Carbaryl and metolcarb had inhibitory activity to EI and EIII but not to EII. MTMC-Z, n-propyl analogue of metolcarb known as a synergist for carbamate insecticide resistance in the leafhopper, Nephotettix cincticeps, had higher activity to all CE's than its mother compound, metolcarb. Propoxur had only low activity to EI and no activity to remaining esterases.

TPP and IBP which were well known as CE inhibitors and also as synergists, exhibited contrastive inhibitory features; TPP showed relatively higher inhibitory activity to EII while IBP inhibited EI and EIII more strong- ly than EII.

When the CE's of the Ogasawara strain were treated with three synergists TPP, DFP and IBP, EI' was strongly inhibited by DFP and $\mathrm{EII}^{\prime}$ was inhibited by DFP and IBP (Table 2). These results suggested that $\mathrm{EI}^{\prime}$ and EII' have similar insecticide susceptibility to EI and EIII, respectively.

\section{Recovery of the CE activity}

After the electrophoresis of the $\mathrm{CE}$ inhibited with insecticide or synergist, the activity was slowly recovered. As shown in Table $3, k_{3}$ (dissociation constant) value, calculated from percentage of recovery, of EII to fenitroxon, dichlorvos, carbaryl and DFP were $0.041,0.095,0.223$ and $0.029 / \mathrm{hr}$, respectively. EII activity recovered more rapidly from inhibition with carbaryl than that from the two organophosphates. As for the recovery of EIII from the inhibition with carbaryl, no recovery occurred after electrophoresis, though $80 \%$ recovery was found during electrophoresis. However, the highest rate, $k_{3}=0.223$ means that it takes $3 \mathrm{hr}$ to recover $50 \%$ of activity and that the CE have no ability to hydrolyze insecticides and synergists used in the present experiment.

\section{Discussion}

The A- and B-type CS's (CE-A and CE-B) classified by hydrolizing specificity to either $\alpha$-NA or $\beta$-NA in $C$. pipiens group (Georghiou and Pasteur, 1978) have been reported to elevate their activity corresponding with the development of insecticide resistance (Georghiou and Pasteur, 1978; Georghiou et al., 1980; Raymond et al., 1987; Ferrari and Georghiou, 1990; Hemingway et al., 1990; Peiris and Hemingway, 1990; Wirth et al., 1990). The high level of activity of CE was recently demonstrated to be due to gene amplification (Raymond et al., 1989; Mouches et al., 1990). In organophosphorus insecticide-resistant strain "Shinjuku" of $C$. pipiens molestus, the gene of CE-B whose part ( $360 \mathrm{bp}$ ) had the same sequence of that in Tem-R strain of $C$. pipiens quinquefasciatus (est B1 gene, Mouches et al., 1990) has also been proved to be strongly amplified (Tomita and Shimada, 1991). It seems that EII of the Okinawa strain is classified as 
Table 4 LG-50 values (confidence limits) of Okinawa strain of C. pipiens quinquefasciatus to fenitrothion and carbaryl with and without synergists.

\begin{tabular}{cccc}
\hline \multirow{2}{*}{ Insecticide } & \multicolumn{2}{c}{ LG-50 (G.L.) $(\mathrm{ppm})$} & \multirow{2}{*}{$\begin{array}{c}\text { Resistance } \\
\text { ratio }\end{array}$} \\
\cline { 2 - 4 } & \multicolumn{1}{c}{ Okinawa } & Ogasawara & 9.5 \\
\hline $\begin{array}{c}\text { Fenitrothion } \\
\text { + DFP }\end{array}$ & $0.041(0.034-0.048)$ & $0.0043(0.0033-0.0053)$ & \\
+ TPP & $0.021(0.018-0.025)$ & & \\
Carbaryl & $0.025(0.021-0.029)$ & & 1.7 \\
+ DFP & $1.98(1.67-2.34)$ & $1.19(1.00-1.41)$ & \\
+ TPP & $1.49(1.27-1.74)$ & & \\
\hline
\end{tabular}

CE-B according to its immunological reaction to the antiserum of Shinjuku CE-B and its molecular weight. The substrate specificity to $\beta$-NA supports the grouping. EIII revealed to be a homodimeric protein is grouped in CE-A. EII' of the Ogasawara strain seems to be grouped in CE-A by the similarity of substrate specificity to that of EIII. EI having $60 \mathrm{kDa}$ molecular weight, however, seemed to be categorized in a third group of $\mathrm{CE}$ because of its specific distribution to the alimentary canal and its electrophoretic mobility.

The present experiment revealed that each type of CE showed a characteristic susceptibility pattern to insecticides and synergists. EI was strongly inhibited by most of the chemicals used. The susceptibility tendency was similar to the other alimentary canal specific CE of the Ogasawara strain (EI') and of the Shinjuku strain (Kono and Tomita, 1991). EII (CE-B) was more strongly inhibited by the oxon type of organophosphorus insecticides, fenitroxon and diazoxon, and, to the contrary, was less inhibited by carbamate insecticides, carbaryl and metolcarb, comparing with the inhibition of EIII (A-CE). When the susceptibility of EII and EIII to two synergists, TPP and IBP, was compared, contrasting results were obtained, i.e., TPP $>$ IBP and TPP $<$ IBP, respectively. The difference in susceptibility to the synergists between CE-A and CE-B was also observed in EII' (CE-A) of the Ogasawara strain (Table 2) and CE-B of the Shinjuku strain (Kono and Tomita, 1991). CE-A, CE-B and the other CE seemed to be discriminated according to those susceptibility patterns.

The Okinawa strain showed a low level of resistance to fenitrothion (Table 4) though it showed a high level of resistance to malathion (Miyata et al., 1984a).

It has already been demonstrated that both EII and EIII had a hydrolyzing activity against malathion (Miyata et al., 1984a, b). The low dissociation constant presented, however, indicated that both $\mathrm{CE}^{\prime}$ 's had no ability to hydrolyze fenitroxon, and, therefore, there must be some other mechanisms, such as sequestering, causing the low level of the resistance. Weak but apparent synergistic activity of DFP and TPP (Table 4) which inhibited the CE-B indicated that sequestering of the $\mathrm{CE}$ had a certain role in the fenitrothion resistance, but that its capacity was limited by the amount of CE proteins produced.

\section{REFERENGES}

Bryan, J. K. (1977) : Molecular weights of protein multimers from polyacrylamide gel electrophoresis. Anal. Biochem., 78: 513-519.

Devonshire, A. L. and G. D. Moores (1982): A carboxylesterase with broad substrate specificity causes organophosphorus, carbamate, and pyrethroid resistance in peach-potato aphids, (Myzus persicae). Pestic. Biochem. Physiol., 18: 235246.

Ferrari, J. and G. P. Georghiou (1990): Esterase B1 activity variation within and among insecticide resistant, susceptible, and heterozygous strains of Culex quinquefasciatus (Diptera: Culicidae). J. Econ. Entomol., 83: 1704-1710. 
Fournier, D., J.-M. Bride, G. Mouches, M. Raymond, M. Magnin, J.-B. Berge, N. Pasteur and G. P. Georghiou (1987): Biochemical characterization of the esterase A1 and B1 associated with organophosphate resistance in Culex pipiens L. complex. Pestic. Biochem. Physiol., 27: 211217.

Georghiou, G. P. and N. Pasteur (1978) : Electrophoretic esterase patterns in insecticide resistant and susceptible mosquitoes. J. Econ. Entomol., 71: 201-205.

Georghiou, G. P., N. Pasteur and M. K. Hawley (1980): Linkage relationships between organophosphate resistance and highly active esterase-B in Culex quinquefasciatus from California. J. Econ. Entomol., 73: 301-305.

Hemingway, J., A. Callaghan and A. M. Amin (1990): Mechanisms of organophosphate and carbamate resistance in Culex quinquefasciatus from Saudi Arabia. Med. Vet. Entomol., 4: 275-282.

Kono, Y. and T. Tomita (1991): Garboxylesterase in an organophosphate resistant Culex pipiens molestus. In: Joint Meeting of Jpn. Soc. Entomol. (51th) and Jpn. Soc. Appl. Entomol. Zool. (35th), Shizuoka (1991), Meeting Abstract, 260.

Matsumura, F. and A. W. A. Brown (1961): Biochemistry of malathion resistance in Culex tarsalis. J. Econ. Entomol., 54: 1176-1185.

Matsumura, F. and A. W. A. Brown (1963): Studies on carboxyesterase in malathion resistant Culex tarsalis. J. Econ. Entomol., 56: 381-388.

Merryweather, A. T., J. M. Crampton and $\mathrm{H}$. Townson (1990): Purification and properties of an esterase from organophosphate-resistant strain of the mosquito Culex quinquefasciatus. Biochem. J., 266: 83-90.

Miyata, T., T. Saito and K. Yasutomi (1984a): Degradation of ${ }^{14} \mathrm{C}$-malathion in vitro by Culex pipiens quinquefasciatus strains resistant and susceptible to malathion. Jpn. J. Sanit. Zool., 35: $103-107$.

Miyata, T., T. Saito and K. Yasutomi (1984b): High malathion degradation in malathion resistant Culex pipiens quinquefasciatus. Jpn. J. Sanit. Zool., 35: 245-249.

Mouches, C., M. Magnin, J.-B. Berge, M. de Silvestri, V. Beyssat, N. Pasteur and G. P. Georghiou (1987): Overproduction of detoxyfying esterases in organophosphate-resistant $\mathrm{Cu}$ lex mosquitoes and their presence in other insects. Proc. Natl. Acad. Sci. U.S.A., 84: 21132116.

Mouches, C., N. Pasteur, M. Agarwal, L. Lemieux, M. Herzog, M. Abadon, V. Beyssat-Arnaouty, O. Hyrien, B. R. de S. Vinsent, G. P. Georghiou and N. Pasteur (1990): Characterization of amplification core and esterase B1 gene responsible for insecticide resistance in Culex. Proc. Natl. Acad. Sci. U.S.A., 87: 2574-2578.

Mouches, C., N. Pasteur, J. B. Berge, O. Hyrien, M. Raymond, B. R. de S. Vincent, M. de Silvestri and G. P. Georghiou (1986): Amplification of an esterase gene is responsible for insecticide resistance in a California Culex mosquito. Science, 233: 778-780.

Pasteur, N., A. Iseki and G. P. Georghiou (1981) : Genetic and biochemical studies of the highly active esterase $\mathrm{A}^{\prime}$ and $\mathrm{B}$ associated with organophosphate resistance in mosquitoes of the Culex pipiens complex. Biochem. Genet., 19: 909919.

Peiris, H. T. R. and J. Hemingway (1990): Mechanisms of insecticide resistance in a temephos selected Culex quinquefasciatus (Diptera: Culicidae) strain from Sri Lanka. Bull. Entomol. Res., 80: 453-457.

Raymond, M., V. Beyssat-Arnaouty, N. Silvasubramanian, C. Mouches, G. P. Georghiou and N. Pasteur (1989): Amplification of various esterase B's responsible for organophosphate resistance in Culex mosquitoes. Biochem. Genet., 27: 417-423.

Raymond, M., N. Pasteur, G. P. Georghiou, R. B. Mellon, M. C. Wirth and M. K. Hawley (1987): Detoxication esterases new to California, USA, in organophosphate-resistant Culex quinquefasciatus (Diptera: Culicidae). J. Med. Entomol., 24: 24-27.

Tomita, T. and T. Shimada (1991): Amplification of carboxylesterase gene in Culex pipiens molestus. Jpn. J. Sanit. Zool., 42: 186.

Wirth, M. C., M. Marquine, G. P. Georghiou and N. Pasteur (1990): Esterase A2 and B2 in Culex quinquefasciatus (Diptera: Culicidae) : Role in organophosphate resistance and linkage. J. Med. Entomol., 27: 202-206.

Yasutomi, K. (1970): Studies on organophosphate-resistance and esterase activity in the mosquitoes of Culex pipiens group. Jpn. J. Sanit. Zool., 21: 41-45.

Yasutomi, K. (1983): Role of detoxication esterases in insecticide resistance. In: Pest Resistance to Pesticides (eds., Georghiou, G. P. and T. Saito), pp. 249-263, Plenum Press, New York and London.

$$
\begin{gathered}
\text { 摘 要 } \\
\text { 殺虫剂抵抗性ネッタイイエカの高活性 } \\
\text { カルボキシルエステラーゼの性質 }
\end{gathered}
$$

malathion に高い抵抗性を示し，他の有機燐剤には 低レベルの抵抗性を示す沖縄系ネッタイイエカから， PAGE によりナフチルアセテート分解活性の高い3種 
のカルボキシルエステラーゼ (CE) が分離された。第 1 は幼虫の中腸にのみ存在し, 第 2 は体のどの部位に もみられるもので，いずれも分子量約 6 万の単量体蛋 白であり，B型 CE に分類された。第 3 は体液には少 量しか存在せず，他の部位に多量にある分子量約12万 の 2 量体蛋白で, A 型 CE に分類された. 3 種の GE は有機燐および, カーバメイト化合物に対して, 特異
的被阻害パターンを示したが，それらの化合物との解 離定数から分解活性はほとんどないことが明らかにな った.この結果から，これらの CE は殺虫㓮と結合し てターゲットである中枢神経への到達を抑制する，、 わゆる sequestration により，抵抗性の要因になって いると推定された. 